\title{
First Records of the Barred Owl in Saskatchewan
}

by Stuart Houston, Yorkton, Sask.

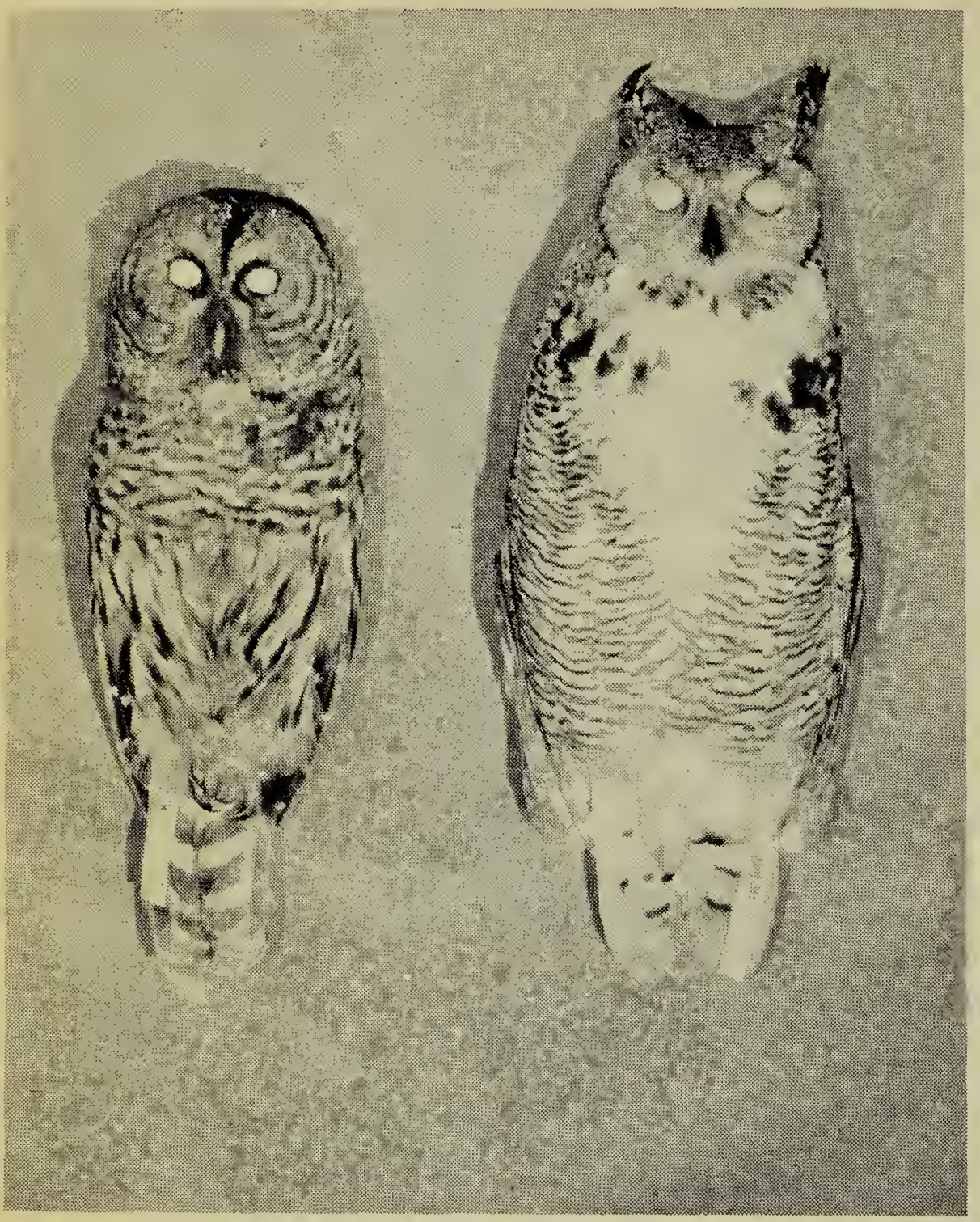

Photo by B. C. Shier

Study skins of Barred Owl (left) and Great Horned Owl (right)

On March 12, 1955, in the Porcupine Mountains about 30 miles north of Norquay, I saw an owl at dusk that I identified as a Barred Owl (Strix $v a r i a)$. However, this was only a relatively brief observation at over 100 feet with $7 \times 50$ binoculars $u n d e r$ imperfect lighting conditions, and I did not report it. In succeeding years, I returned to the area several times in the hope of obtaining a specimen, but without success. Every trapper and hunter I met was questioned and shown the pictures of the various owls in Peterson's Field Guide.

No further definite information about the Barred Owl was obtained until June, 1958, when my wife and I flew into Cumberland House for five days of birding at Saskatchewan's oldest settlement. It was here that Samuel Hearne, John Richardson, $\mathrm{T}$ h o m a s Drummond and Roderick MacFarlane recorded some of the first observations of birds in what is now Saskatchewan. At Cumberland House we visited Russell Robertson, manager of the Hudson's Bay Co. fur lease, whose cabin is picturesquely situated some three miles upstream along the Old Channel of the Saskatchewan River. Robertson gave a perfect description of the call of the Barred Owl, and told how he had first heard one in March, probably in 1948, along the portage between his cabin and Egg Lake. In June of the same year he had shot the owl and compared it with the illustration in Taverner's Birds of Canada, thus satisfying himself as to its identity. He had not seen one since.

Robertson kindly wrote this spring to say that he had heard a Barred Owl calling on the evening of March 8 (1959). He later collected the bird which he mailed from The Pas on June 4, and the roughed-out and salted skin was then forwarded to the Saskatchewan Museum of Natural History (see photo).

Robertson reports further that Sam Waller has two male specimens of the Barred Owl in his little museum at the Pas, Manitoba. Waller reports that they were collected at Reader Lake near The Pas, less than 20 miles from the Saskatchewan boundary, on September 15, 1941 and October 11, 1946.

Another Barred Owl was shot in early December, 1958 at High Hill, northeast of Kelvington, by Steve Waycheshen near his mink traps in heavy spruce and poplar bush near a lake shore. At the time, he did not realize how scarce it was, and the specimen was not preserved. 